FACTA UNIVERSITATIS

Series: Law and Politics Vol. 15, N 2, 2017, pp. 127 - 144

DOI: 10.22190/FULP1702127J

Original Scientific Article

\title{
THE FOOTHOLDS OF AN INTEGRATIVE BIOETHICS IN THE WORK OF VAN RENSSELAER POTTER ${ }^{1}$
}

\author{
UDC 608
}

\section{Hrvoje Jurić}

Faculty of Humanities and Social Sciences, University of Zagreb, Croatia

\begin{abstract}
Regardless of the still persistent tendencies to narrow the concept of bioethics down to (bio)medical or even clinical bioethics, it is clear that today's bioethics integrates discussions of a much wider range of issues - from bio-medical to global-ecological. The broadening of the field of bioethics is the result of the insight that the issues of the technoscientific era humanity faces are interwoven with the issues that regard other living beings and nature as a whole. This insight into the interweavement of the issues involved (and the interweavement of the relationships themselves within the living world) has brought about the networking of various sciences, professions and non-scientific views, which we know under the names of multi-, inter-and trans-disciplinarity, and pluriperspectivism. However, bioethics should not be satisfied with a mere mechanical gathering of various disciplinal views and worldviews, but should aspire after real integration, the shaping of a unified platform for discussion of the ethical problems regarding life in all its forms, shapes, degrees, stages and manifestations. Developing the starting premises of this platform is the task of "integrative bioethics". In order to do so, taking account of the work of Van Rensselaer Potter cannot be avoided, since his idea of bioethics and the development of his bioethical thought extensively coincide with what bioethics generally means, as well as with its historical transformations: from the moment he coined the term 'bioethics', through having founded so-called "bridge bioethics" to the reformulation and expansion of the contents of bioethics into so-called "global bioethics". The aim of this paper is to examine the extent to which Potter's work can serve as a stimulus and be the foothold of the goal to establish bioethics as integrative bioethics.
\end{abstract}

Key words: bioethics, integrative bioethics, interdisciplinarity, pluriperspectivity, Van Rensselaer Potter

Received May $17^{\text {th }}, 2017$ / Accepted May $22^{\text {nd }}, 2017$

Corresponding author: Hrvoje Jurić

Faculty of Humanities and Social Sciences, University of Zagreb, Ivana Lučića 3, HR-10000 Zagreb, Croatia E-mail: hjuric@ffzg.hr

${ }^{1}$ This article was previously published in German, Croatian, and Macedonian: Stützpunkte für eine integrative Bioethik im Werk Van Rensselaer Potters. In Čović, A., Hoffmann, Th. S. (eds.), Integrative Bioethik / Integrative Bioethics, Academia Verlag, Sankt Augustin, 2007, pp. 68-92; Uporišta za integrativnu bioetiku u djelu Van Rensselaera Pottera. In Valjan, V. (ed.), Integrativna bioetika i izazovi suvremene civilizacije, Bioetičko društvo u BiH, Sarajevo, 2007, pp. 77-99; Potpirnite točki za integrativnata bioetika vo deloto na Van Renselar Poter, Filozofija, Vol. 10 (2011), No. 31, pp. 19-31. 


\section{BIOETHICS AND INTEGRATIVE BIOETHICS}

What is - bioethics? The answer to this simple question is not at all simple. In other words, there is no single definition of bioethics that would satisfy all those who consider themselves to be bioethicists or those who tackle problems they call bioethical. On the contrary, there are many and - more importantly - many different definitions of bioethics which are frequently diametrically opposed.

The very fact that the discussions and disagreements over the definition itself of bioethics have persisted ever since its inception with lasting intensity is rather indicative. However, here I shall not enter the debate on either the causes or the consequences of the above, but shall rather only cite a few examples that illustrate the different conceptions (or self-conceptions) of bioethics.

The first group of authors are those who take bioethics as a discipline that tackles issues pertaining to clinical practice, healthcare systems, biological, biomedical and pharmaceutical research and research result applications, and other issues concerning human life and health in general. This understanding of bioethics is narrower and its nature human biomedical since the horizons of a bioethics thus understood do not embrace either those questions that are not directly related to human health or those directly related to other living beings and nature as a whole. ${ }^{2}$ Hence, the first group of authors often uses the terms 'bioethics' and 'biomedical ethics' as synonymous.

Following this trail a large number of $a d$ hoc definitions of bioethics have emerged, which can be found in diverse Internet encyclopaedias, newspapers, television shows, etc., although such conceptions of bioethics are also present in those authors who have tackled the question of the definition of bioethics rather seriously. Thus, for example, Daniel Callahan, one of the pioneers of bioethics, considers bioethics to be a place at which general interest in ethics meets the medical profession (Callahan, 1988: 2). The authors of the acclaimed book Principles of Biomedical Ethics, Tom Beauchamp and James Childress, also equate bioethics with biomedical ethics (Beauchamp, Childress, 2004). The same is also done by Peter Singer and Helga Kuhse, the editors of two books that are indeed influential and crucial to the establishment of bioethics - namely Bioethics: An Anthology (Kuhse, Singer, 2003: 1-7) and A Companion to Bioethics (Kuhse, Singer, 2004: 3-11).

Even though this tendency to narrow the concept of bioethics down to medical or biomedical ethics is still strong, particularly in the Anglo-American world, the bioethical discourse has become increasingly aware of the fact that bioethics is simply not (or rather not any longer) synonymous with new medical or biomedical ethics, and that it embraces a much wider array of issues, ranging from clinical-medical to global-ecological.

\footnotetext{
${ }^{2}$ Discussions of issues such as environmental protection as a condition for the preservation and sustenance of human life and health, and animal testing exclusively in respect of the issues of human medicine are examples demonstrating that the issues concerning other living beings and nature do enter the framework of humanbiomedical bioethics to a certain degree, although - as a rule - as 'additional' and side issues because both the perspective and ultimate reach of its perception remain limited to that which is human. - It seems paradoxical that even Peter Singer, one of the leading bioethicists and "animal philosophers", considers the questions of the moral status of animals and people's relationship to animals, as well as environmental protection issues, within the context of so-called "practical ethics" (Singer, 2003), while his books that we can indeed consider to be a testimony to his understanding of bioethics - since they provide an overview and with it both the concept and programme of bioethics as a discipline in some way - treat the same issues only in a limited way, i.e. in the above sense or within the context of the discourse on human-biomedical issues (Kuhse, Singer, 2003; Kuhse, Singer, 2004).
} 
The "Bioethics" lexicon-type entry written by Otfried Höffe in his Lexicon of Ethics can serve as an example of the second group of definitions of bioethics:

"Bioethics (...) is understood to be an interdisciplinarily founded science of survival, the main aim of which is to build bridges between the humanities and the natural sciences. Directed against a merely instrumental approach to nature, bioethics discusses the economic, social, political and cultural presuppositions of people's relationship to nature. Extended to the field of biomedical ethics, it deals with the moral questions of birth, life and death, particularly in the light of the more recent developments and possibilities introduced by biomedical research and therapy. It researches, amongst other things, the moral dimensions of abortion, sterilisation and birth control, (genetic) manipulation, euthanasia, experiments on humans (...), as well as animal protection." (Höffe, 1997: 28)

The "Bioethics" entry, written by Daniel Callahan for the second edition of the Encyclopedia of Bioethics, also follows this trail, at least in some measure. By contrast to Callahan's earlier definition (published in 1988), in the Encyclopedia (published in 1995) he notably widens his understanding of bioethics. In other words, Callahan interprets the birth of bioethics as the result of the synergy of two factors. These are: extraordinary technological progress in the field of biomedicine and gradual awakening to the environmental hazards posed by the human appetite for economic progress and the domination of nature (Callahan, 1995: 248). He calls bioethics "a child of remarkable advances in the biomedical, environmental, and social sciences", born to ancestors "seeming to alter forever what can be done about the vulnerabilities of nature and of the human body and mind" and which concerns, amongst other things, "our common duties to each other and to nature" (Callahan, 1995: 247-248). ${ }^{3}$

Christoph Rehmann-Sutter's paper "Bioethics" - published in the comprehensive Handbook of Bioethics, edited by Marcus Düwell, Christoph Hübenthal and Micha H. Werner - is also worth mentioning within this context. He calls attention to the controversies surrounding both the understanding and definition of bioethics, although he sides with the wider understanding, which comes to the fore not only in his definition of bioethics, ${ }^{4}$ but also in his list of "the fields of practice discussed" in bioethics, which are as follows: professional relationships, procreation, transplantation, medical genetics, end-of-life decisions, healthcare systems, experiments on humans, as well as animal testing and animal breeding, biotechnology, patenting, and nature (Rehmann-Sutter, 2002: 250-252).

Furthermore, in his paper on bioethics - published in the collected papers Applied Ethics, edited by Annemarie Pieper and Urs Thurnherr (1998) - Ludwig Siep defines bioethics as "that field of ethics which centres on the right ways of human conduct in relation to either the living (...) or to nature as a whole" (Siep, 1998: 16).

With respect to the question of defining the problems that bioethics does and is to deal with, the above two papers advocate a wider understanding of bioethics, which I myself

\footnotetext{
${ }^{3}$ However, although declaratively he does widen the field of bioethics, the fact that in the paper Callahan, as well as a number of other authors, places most emphasis on human-biomedical issues must not be neglected. He explicitly states: "While the primary focus of this entry will be on medicine and health care, the scope of bioethics - as the encyclopedia as a whole makes clear - has come to encompass a number of fields and disciplines broadly grouped under the rubric 'the life sciences'. (...) Yet it is the medical and biological sciences in which bioethics found its initial impetus, and in which it has seen the most intense activity. It thus seems appropriate to make that activity the center of attention here." (Callahan, 1995: 248)

4 "Bioethics is considered to be facing the moral dimensions critically in those contexts of action that concern the biosciences, and they are biomedicine, biotechnology and ecology." (Rehmann-Sutter, 2002: 247)
} 
endorse. However, what I do find problematic in them is the fact that both - either implicitly (Rehmann-Sutter) or explicitly (Siep) - take bioethics as a sub-discipline of philosophical ethics or, more precisely, as a branch of applied ethics.

This view on the status of bioethics within the classification of philosophical-ethical disciplines (including the problems surrounding this view) is illustrated by the programmatic introductions to the books Applied Ethics (Annemarie Pieper and Urs Thurnherr), A Companion to Bioethics and Bioethics: An Anthology (Helga Kuhse and Peter Singer).

Pieper and Turnherr divide philosophical ethics into general ethics and applied ethics. General ethics is further sectioned into descriptive, normative and meta-ethics, and applied ethics into bioethics (ecological, medical and animal ethics), social ethics (law, business and political ethics), the ethics of science (the ethics of technology and evolutionary ethics), philosophical praxis, feminist ethics and pedagogical ethics (Pieper, Thurnherr, 1998: 9).

Irrespective of the fact that the above scheme is clearly structured and that each of the above branches of applied ethics is extensively treated in separate texts, in the end we are left with the impression that this dissection of the field of (applied) ethics contributes neither to the clarity nor to the coherence of the system. Following a separate entry on bioethics (by Ludwig Siep), bioethical topics are also discussed in separate entries on "ecological ethics" (Andreas Brenner), "animal ethics" (Urs Thurnherr), "medical ethics" (Hans-Martin Sass) and "psychological ethics" (Alfred Schöpf), and are also present in a number of other entries such as on "the ethics of technology" (Günter Ropohl) and "the ethics of science" (Hans Lenk and Matthias Maring). I take this to be an indicator of the impossibility of distinctly demarcating the wide and self-intertwined field of bioethics as is attempted in this book, and an indicator of the impossibility of "cramming" bioethical issues that are polyvalent in and of themselves into the narrow and monodisciplinal framework of (applied) philosophical ethics. ${ }^{5}$

On the other hand, Kuhse and Singer define bioethics as "a specialized, although interdisciplinary, area of study", even though for them it also remains "a branch of ethics, or more specifically, of applied ethics" (Kuhse, Singer, 2003: 1), which even at first glance seems contradictory. In other words, if something is disciplinal, defined as a discipline and demarcated as such, it cannot also and at the same time (within itself) be inter-disciplinary precisely because interdisciplinarity implies the interrelations between two or more disciplines. More specifically, if bioethics is only a branch of (applied) ethics as a discipline, or only a sub-discipline, then it cannot be inter- but only mono-disciplinal with possible "applications" in some specific fields, i.e. with emphasis being placed on those fields. If, on the other hand, bioethics is an interdisciplinary field then it cannot be a branch of ethics as a discipline, but should bring together various disciplines with ethics playing a more or less important role. Thus, as far as Kuhse and Singer's definition of bioethics is concerned, I do not hold its first part to be problematic ("a specialized, although interdisciplinary, area of study"), since something can be both interdisciplinary and specialised, i.e. focused on a certain issue or an entire range of issues. What I do consider to be problematic is the inclusion of the second part of their definition ("a branch of ethics, or more specifically, of applied ethics"), since something cannot be interdisciplinary yet remain in the domain of a single discipline.

\footnotetext{
${ }^{5}$ I leave aside the fact that some of the branches of applied ethics are here classified according to the principle of their approach to the issues of ethics (feminist ethics, evolutionary ethics) while the entire classification is done according to the principle of the subject (field) of their ethical discourse. As it is not my intention to scrutinise this problem here, I also leave aside the discussion of the very concept of "applied ethics", which deserves much closer inspection.
} 
To make matters worse, the same authors also define bioethics - although in a different place - as "a modern version of a much older field of thought, namely medical ethics", even though they further claim that, in relation to medical ethics, bioethics has "a distinctly different approach", which makes it a new and distinct field of research (Kuhse, Singer, 2004: 3-4), though it does remain primarily centred on medical issues. According to Kuhse and Singer, this "new medical ethics (...) was almost from the beginning an interdisciplinary enterprise", which means the following:

"While ethics had been the near-exclusive domain of moral philosophers and religious thinkers, bioethics crossed the boundaries not only of medicine, nursing and the biomedical sciences, but of law, economics and public policy as well." (Kuhse, Singer, 2004: 10)

If I understand correctly, for Kuhse and Singer bioethics is both applied ethics which concerns not only ethics and its application, and medical ethics which concerns not only medicine and ethics. Without any further attempt to resolve their contradictions, I shall only highlight two points from their texts, which I take to be typical of one's understanding of bioethics, and which still prevail in bioethical circles and even beyond: bioethics is (new) medical ethics and/or a branch of (applied) ethics.

By contrast, I hold that bioethics is neither mere medical or biomedical ethics, nor a sub-discipline of philosophical ethics, although philosophical ethics and philosophy as a whole do play an important - moreover, key - role in bioethics, particularly in respect of both the general and specific tasks of bioethics.

This brings to the fore the fact that the problem of defining bioethics is not only a question of defining the topics or field of bioethics, but is also a question of placing it within the existing system of knowledge and science, i.e. its foundations, methodology, etc. Yet, I shall here focus on the question of defining the topics or field of bioethics, because I believe that - in a "meta-bioethical discussion", so to speak - this problem seeks our attention first before we can even think about approaching and attempting to solve any further and far more complex issues pertaining to bioethics itself.

I shall end this brief overview of attempts to define bioethics with something that must not be ignored. It is the "official definition" of its kind of bioethics; namely, the definition supplied by Warren Thomas Reich in the second edition of the Encyclopedia of Bioethics from 1995. According to Reich, bioethics is:

“... the systematic study of the moral dimensions - including moral visions, decisions, conduct and policies - of the life sciences and health care, employing a variety of ethical methodologies in an interdisciplinary setting." (Reich, 1995: XXI) ${ }^{6}$

It is indicative that bioethics is not thought of as a science and a scientific discipline by either the above "official definition" or the vast majority (or at least a large number) of efforts to define bioethics, given that any such characterisation would have to imply a

\footnotetext{
${ }^{6}$ Here it must be noted that, much like in Callahan (and his extended view on the field of bioethics), in Reich's definition and some other of his claims, as well as in the structure and content of the Encyclopedia of Bioethics, we can recognise an approach to bioethics that essentially does open its field to issues that concern other living beings and nature as a whole, but that in fact remains limited to human, i.e. human-biomedical, issues. Namely, from the approximately two hundred entries in the Encyclopedia only a very small number of them are about questions that concern other living beings (i.e. animals and plants) and nature (i.e. the natural environment). These are: "Animal Research", "Animal Welfare and Rights", "Climatic Change", "Endangered Species and Biodiversity", "Environmental Ethics", "Environment and Religion" and "Nature", as well as the following in some sense: "Agriculture", "Environmental Health", "Environmental Policy and Law", "Genetic Engineering (Animals and Plants)", "Life", "Patenting Organisms", "Sustainable Development" and "Veterinary Ethics".
} 
number of features that bioethics lacks, does not yet have and might never have or might not be able to have.

Although the following statement may seem inappropriate for an attempt to demarcate and define bioethics, particularly in respect of strict scientific and disciplinal requirements, I believe that we should not aspire after any such scientisation and disciplinisation of bioethics, at least not in the sense that we now direct all our attention and efforts towards achieving this goal because - the advantages of bioethics, I believe, lie precisely in its "definite indefiniteness".

As far as principles are concerned, bioethics should aspire to have its methodological principles of discourse on bioethical issues established, rather than to have a solid and defined set of bioethical principles verified in the sense of principlism which the early days of bioethics tended towards (Beauchamp, 1996; Beauchamp, Childress, 1994).

In this sense and following the trail of those definitions that reflect a wider understanding of bioethics, I am now offering a synthetic, yet still starting definition of it:

Bioethics is an open field of encounters and dialogue between different sciences and professions, and diverse approaches and worldviews, which gather to articulate, discuss and solve ethical questions concerning life, life as a whole and each of its parts, life in all its forms, shapes, degrees, stages and manifestations.

The underlying presupposition of this definition is an insight into the interlacement of relationships within the living world, and into the interlacement of the problems that humanity is facing in this techno-scientific era on the one hand, and that also concern other living beings and nature as a whole on the other.

The chief characteristics of bioethics thus understood can indeed be summarised using the concepts of multi-, inter- and trans-disciplinarity, pluriperspectivism and integrativity.

Multidisciplinarity refers to - the gathering of all human sciences and professions relevant to bioethical issues; interdisciplinarity to - the promotion of dialogue and of finding a way in which these disciplines would collaborate; and transdisciplinarity to - the overcoming of their mutual differences, or the incorporation of these differences in a unique, bioethical view focused on questions that cannot be fathomed from the perspective of a single science or a single field of knowledge.

This introduces the concept of pluriperspectivism to the game, so to speak. In brief, this concept refers to the incorporation and mediation through dialogue of not only scientific but also of non-scientific or beyond-scientific contributions, including different modes of reflection, ${ }^{7}$ different traditions of thought and culture, i.e. diverse views that rest on cultural, religious, political and other specificities.

\footnotetext{
${ }^{7}$ E.g., art, i.e. artistic reflection (which is mostly entirely excluded from "serious debate") could play an important orientative role in (bioethical) pluriperspectivism. In this sense, the contribution made by the book Science and Poetry by Mary Midgley (2001) is highly valuable, although we can find stimuli to reflect on the possibility of non-scientific (poetic and other artistic) modes of reflection contributing to the integration of human knowledge and our sensitisation to questions concerning the survival of man and nature in countless places. Aldo Leopold is against the "ironbound taboo which decrees that the construction of instruments is the domain of science, while the detection of harmony is the domain of poets". In his work A Sand County Almanac Leopold not only claims but also shows by his own example (much like Henry David Thoreau did before him in his work Walden, for instance) that scientific and poetic reflection are equally valuable modes of man's approach to both nature and himself. Daniel Berthold calls Leopold's approach "poetic science" (Berthold, 2004), while J. Baird Callicott, using the titles of two of Leopold's essays, namely "Land Ethic" and "Conservation Esthetic", talks of Leopold's "Land Aesthetic" (Callicott, 1987). - As a further example, we can also mention the book Le scaphandre et le papillon by Jean-Dominique Bauby (1997), which has done a lot in
} 
The concept of plurality in bioethics "falls short" if we limit ourselves to "the plurality of scientific disciplines" and "the plurality of ethical orientations", as rightly pointed out by Ante Čović:

"The exceptionality and innovativeness of bioethics, its true proprium, rests on the fact that it and its methodology engage both non-scientific and beyond-ethical perspectives on an equal footing in discussion and the solving of problems..." (Čović, 2005: 150)

Yet, bioethics should not content itself with a mere mechanical gathering of diverse perspectives, different disciplinal and world-views, but should aim at true integration, the development of a unified platform for discussion of the ethical problems concerning life - both as a whole and in all its contextually definable nuances. Integrativity, therefore, refers to the task (or capability) of bioethics to bring all the differences that have been discussed together into a unique bioethical view, rather than a disciplinal or a disciplined scientific framework. This is more about the promotion of a bioethical view in different disciplines and approaches than about the forcing of diverse particular views into a single, bioethically disciplined mould. Integrative bioethics could, in this sense, be conceptualised as a solid body in space, whose role is to permanently absorb and emit energy towards other bodies in space, which are sensitive to this energy.

Furthermore, this is more about bioethics offering an orientation than about bioethics establishing the final objective truths about bios. Supplying orientations for answers to some of the key questions of humanity and the planet Earth, thus, represents the first and most important aim of integrative bioethics.

In this sense, Ante Čović holds that all the disciplines and perspectives integrated into the bioethical field have an "orientative value", and that all of them can make "contributions to the interactive development of the orientation", which means that "bioethics has a single aim - providing orientation". Accordingly, Čović defines bioethics as "an integrative orientative science", i.e. as "a pluriperspectival field, in which footholds and measures for orientation in the questions concerning life or the conditions and circumstances of the preservation of life are being created through the interaction of diverse perspectives" (Čović, 2005: 150-151).

The second and also very important goal of integrative bioethics is nurturing and articulating the growing bioethical sensibility, ${ }^{8}$ which is no longer in the embryonic stage, although it has been developing and shaping rather slowly due to the still strong systematic counter-tendencies.

Accordingly, the integration of different (and all) topics and issues concerning bios, and the integration of different (and all) approaches to these topics and issues is the underlying presupposition of integrative bioethics.

The nature of bioethical issues and bioethics itself - naturally, if understood in the aforementioned sense - does not allow enclosure into the framework of an individual discipline or approach. Moreover, what comes to the fore in bioethics is that which should, in

terms of raising awareness of the problems that emerge in the encounter between human life and technicalised medicine, which Ante Čović calls "bio-poetic" and legitimately interprets with the help of the apparatus of existentialism in general and Jaspers's philosophy of existentialism in particular (Čović, 1998a). - In any case, it holds true that poetry and any other art (not as "un-rational" approaches, but as different ways of reflection) should not be excluded from thought that aspires after integrativity because art has the power and ability to unveil new dimensions of problems that ultimately cannot be shed light on by the apparatus of science alone.

${ }^{8}$ The term 'bioethical sensibility' was, as far as I am aware, first used by Ante Čović, who defines the same as a "new planetary susceptibility" which could "limit the existing science by integrative concerns" (Čović, 1998b: $565)$. 
fact, be the case in all reflection: that the path must be followed from problems to conceptualisations, from issues to seeking appropriate approaches and orientations, and not vice versa and most definitely not in the sense of causality. But this requires that we conceptualise and realise the integration of topics and problems on the one hand, and of approaches on the other, which could be called horizontal and vertical integration following the guidelines of an integrative bioethics.

The clearer the understanding that humanity is standing on the brink of a new post-technoscientific era, characterised by a new and different approach to science and technology and the idea of limitless and aimless scientific-technological progress, and a new and different approach to life or the living world - the clearer the need for a comprehensive bioethical conception, such as integrative bioethics. ${ }^{9}$ Novel questions require novel answers, and bioethics in the integrative sense has the capacity to provide orientatively valid answers.

Developing the concept of integrative bioethics is ambitious also in the sense that it aims beyond the limits of bioethics. In other words, the model of integrative bioethics - owing to its aspirations to solve the fundamental problems of interdisciplinary and interperspectival discussions - could indeed serve as a model for an integrative perspective on non-bioethical problems as well, i.e. as a model for integrative discussions in other spheres of human action and of questions that are not bioethical.

However, if we are to discuss only bioethical questions (i.e. questions of bioethics alone), talk of integrative bioethics is only logical because the process of establishing and institutionalising bioethics has come a long way, even though no consensus has been reached yet on either its definition or footholds. This, therefore, requires that we give serious thought to what bioethics is, what we do and can expect from it, what its reach is so far, its future development and aims - in sum, the past and future of bioethics.

\section{VAN RENSSELAER POTTER'S BIOETHICS}

Accordingly, drawing attention to a conception of bioethics that is most closely connected with the origin of bioethics as such seems useful at this stage. It is the bioethics of Van Rensselaer Potter (1911-2001), an American scientist and bioethicist.

By profession, Potter was a biochemist. He devoted his entire scientific career to cancer research. Some of his findings were highly noted, and he educated generations of successful scientists (Trosko, Pitot, 2003). But, we are here not interested in Potter as an oncologist, but in Potter as a bioethicist; more specifically, as "the father of bioethics". In other words, the term 'bioethics' was coined and first used by precisely Potter back in 1970 in two of his papers (Potter, 1970a; Potter, 1970b), and a year later in his book Bioethics: Bridge to the Future (Potter, 1971). In this book, announced by a number of

\footnotetext{
${ }^{9}$ This aspect of the novelty of integrative bioethics - i.e. the integration of the (bio)ethical approach to those questions that concern humanity with those that concern other living beings and nature as a whole - is philosophically elaborated in great detail by Heike Baranzke in Würde der Kreatur? Die Idee der Würde im Horizont der Bioethik, particularly in the chapter "Auf der Suche nach einer integrativen Bioethik" (Baranzke, 2002: 309-349). Baranzke systematically and historically follows the development and interrelations between the ideas, concepts and traditions of "human dignity" and "the dignity of the creature", pointing to "the indicative function of the concept of 'the dignity of creature' in the need for an integratively bioethical and integratively legal reflection" (Baranzke, 2002: 312), in which "seeking an integrative solution" (Baranzke, 2002: 310) or, more specifically, "seeking an integrative bioethics founded on Kant" (Baranzke, 2002: 313) is the aim or at least the challenge.
} 
his previously published papers, Potter expounded his own bioethical position, which he called "bridge bioethics". He once said:

"The word bridge is used because Bioethics was seen as a new discipline that would forge a bridge between Science and the Humanities, or, more explicitly, a bridge between Biological Science and Ethics..." (Šegota, 1999: 171)

On the other hand, Potter's term 'bioethics' was - as was later held by H. Tristram Engelhardt - "profoundly heuristic" because it suddenly crystallised an entire set of questions, bringing together a wide cluster of important cultural concerns. Accordingly, Engelhardt classified the term 'bioethics' under those words that can "assemble a rich set of images and meanings and thus help us to see relations between elements of reality that were previously separated in our vision and thought of only as disparate" (Engelhardt, 1988: VII, XI).

Naturally, this was not about novel and attractive words and syntagmata, but about what was thought and intended by them. With the purpose of solving the burning questions of humanity and with the help of what he called bioethics, Potter's intension was to contribute to the bridging of the gap between the sciences for humanity to be able to build a solid "bridge to the future". He was motivated, on the one hand, by the uninterestedness of ethics and the other humanities and social sciences in the growing dilemmas in medical practice and biomedical research, and in ecological questions, which were not as widely discussed at the time as they are today. On the other hand, his bioethical ideas were driven by the uninterestedness of both doctors and natural scientists in reflecting on and conceptualising the pressing problems they face(d) daily in their practice. The following passage is a brilliant illustration of Potter's frustration with the existing state of affairs in the sciences (principally the natural and technical sciences) and society, which led him to ideas he later called bioethics:

"As individuals we cannot afford to leave our destiny in the hands of scientists, engineers, technologists, and politicians who have forgotten or who never knew these simple truths. In our modern world we have botanists who study plants and zoologists who study animals, but most of them are specialists who do not deal with the ramifications of their limited knowledge." (Potter, 1971: 1)

In other words, Potter's own work experience in the field of biomedicine, which was facing new challenges owing to the accelerated development of technology, was what inspired him first to mould bioethics. Yet, his second and even more important inspiration came from the thoughts of Aldo Leopold, an American forester, conservationist, ecologist and writer, whose work was the forerunner of contemporary eco-philosophy, i.e. the prototype of what was later to be called deep ecology. Leopold's land ethic - whose core is elaborated in an essay of his bearing the same name (Leopold, 1987: 201-225), and which is explained in more detail and supported by examples in the other essays from his book A Sand County Almanac, and in his later work - required a revolution in human thought and action, a revolution so indispensable for ensuring the survival of humanity and the planet Earth.

"A land ethic of course cannot prevent the alteration, management, and use of these 'resources', but it does affirm their right to continued existence, and, at least in spots, their continued existence in a natural state." (Leopold, 1987: 204)

According to Leopold, land is a biotic mechanism or, better yet, a biotic community, it "is not merely soil; it is a fountain of energy flowing through a circuit of soils, plants, and animals" (Leopold, 1987: 216). 
Potter considered Leopold a proto-bioethicist, the founder of what he later called bioethics:

“As the first person to couple and define the words 'land' and 'ethic' in ecological terms, Leopold was unquestionably the first bioethicist; he was first to envision a new ethical basis for human conduct, first to develop an ecological ethic (which he called the land ethic), and first to explain clearly why it is needed." (Potter, 1988: XIII)

Following Leopold's trail, Potter gained insight into a network of problems concerning life, into a network of the micro- and macro-levels of life, into the fact that life represents an intricate system of interactions. This insight into a network of problems implies the need to network approaches, i.e. the need for an all-embracing perspective on the issues of the health and survival of humanity, other living beings and nature or - life as a whole.

In this sense, the primary task of bioethics is the integration of biological knowledge with knowledge of human value systems:

"I take the position that the science of survival must be built on the science of biology and enlarged beyond the traditional boundaries to include the most essential elements of the social sciences and the humanities with emphasis on philosophy in the strict sense, meaning 'love of wisdom'. A science of survival must be more than science alone, and I therefore propose the term Bioethics in order to emphasize the two most important ingredients in achieving the new wisdom that is so desperately needed: biological knowledge and human values." (Potter, 1971: 1)

Correspondingly, the starting point of Potter's bioethics is the thesis that ethics cannot be separated from biological facts. This thesis could be interpreted in the following way: Ethics has traditionally centred around good life, while life as a biological fact has remained beyond its sight. Today, however, ethics can no longer leave life in the biological sense aside, even though it must not, at the same time, lose sight of the fact that "bare life" - although it does have its own inherent value - is only the presupposition of good life. In other words, life and good life can be dissociated methodologically but not actually. This has been thrown light on by both biomedical and ecological issues. What is more, the biomedical, i.e. natural scientific, party should reach the same conclusion, only reversely.

Potter's insight into a network of problems and the need to network approaches to these problems, i.e. the problems of the whole life and the life as a whole, involves both an all-embracing and a long-term perspective, which is to focus on what Potter holds to be the aim of bioethics - the survival of humanity and the planet Earth. This is one of Potter's first formulations of this request:

"An instinct for survival is not enough. We must develop the science of survival, and it must start with a new kind of ethics - bioethics." (Potter, 1971: 3)

Potter later explicates that this is neither about mere or miserable survival, nor about idealistic or irresponsible survival; this is about what can be called acceptable survival (Potter, 1988: 43-52).

As any survival, "acceptable survival" is an adaptation, and not just any adaptation, but both a biological and cultural (neither a biological alone, nor a cultural alone) adaptation.

Accordingly, Potter (just as Leopold and a number of other authors before him) believed that the human population must be stabilised, and that this both can and should be assisted by fertility control. This is another example of biomedical questions converging with ecological ones under a single umbrella perspective. Besides being vitally important for Potter, this problem also exemplifies the paradigmatic case of his global-bioethical purpose: 
"An example of an issue in global bioethics involves the medical options concerning human fertility in confrontation with the ecological need to limit the exponential increase in the human population." (Potter, 1988: 2)

Furthermore, this global-bioethical perspective does not concern the human population alone. Although the short-term (medical-bioethical) perspective is focused on human problems (on human and personal health, and a healthy environment), the long-term (ecological-bioethical) perspective focuses on the survival of the species and a healthy ecosystem, which no longer involves only people. This is the true import of (global) bioethics. $^{10}$

Not long after Potter's "invention of bioethics", the term was accepted by a circle of people from Georgetown University, who built it into the name of the then newly founded Kennedy Institute for Study of Human Reproduction and Bioethics. However, regardless of how significant this was for the future development or accelerated expansion of bioethics which Potter himself admitted - this was, nevertheless, a wrong and utterly reduced understanding of his original intention engrained into the term 'bioethics'. This was most closely associated with "forgetting" to credit Potter with having coined the term 'bioethics' and with having initiated the bioethical discourse. In 2001 Potter wrote the following:

"For a long time 1970-1990 there was no one who recognized my name and wanted to be part of a mission. In the USA there was an immediate explosion of the use of the word Bioethics by Medical People who failed to mention my name or name any of my four publications 1970-1971. Unfortunately, their image of Bioethics delayed the emergence of what now exists." (Potter, 2001)

Peter J. Whitehouse substantiates Potter's thoughts:

“In the United States, Potter's original coinage of the term 'bioethics' in 1970 (...) seems to be viewed by some as an irrelevant historical note. Whereas some have recognized his contributions and fostered a broader view of bioethics (...), Potter's legacy is not taught in many biomedical ethics programs. Moreover, he is not adequately included in the important accounts of the history of our field..." (Whitehouse, 2003: 26)

Nonetheless, in the above-mentioned encyclopaedic note on bioethics Daniel Callahan mentions Potter within the context of outlining the developmental path of bioethics - from Potter's comprehensive concept through its reduction to the field of clinical and medical ethics to the re-widening of the concept, underlining that the "anti-Potterian" "heavy, almost exclusive emphasis on the moral obligations of physicians and on the doctor-patient relationship (...) was not capacious enough to embrace the huge range of emerging issues and perspectives" (Callahan, 1995: 250).

Potter is also mentioned by Helga Kuhse and Peter Singer in the introductions to their two aforesaid collected papers (Kuhse, Singer, 2004: 3; Kuhse, Singer, 2003: 1). But having taken over and having popularised the concept in the narrow sense, Kuhse and Singer only briefly

\footnotetext{
${ }^{10}$ In his book Bringing Life to Ethics. Global Bioethics for a Humane Society, Michael W. Fox, one of Potter's closest and like-minded associates, writes that "global bioethics promotes and unifies Earthcare, Peoplecare, Animalcare, and Healthcare for the good of all", and that "global bioethics calls us to give equally fair consideration to three spheres of moral concern: human well being (rights and interests), nonhuman well being (rights and interests), environmental well being (biodiversity and ecosystemic integrity). Global bioethics calls us to be accountable for our actions and appetites in relation to these three spheres; and to examine how well society, our politics, laws, economies (industry and commerce), religious, educational and other traditions and institutions, as well as our own personal lives, are in accord with the bioethical principles that unify these three spheres in the light and language of compassion, humility, and reverence for the sanctity of life." (Fox, 2000)
} 
state the fact that Potter, being the author of the concept of 'bioethics', advocated a different and much wider understanding of the concept than they do. Kuhse and Singer, it seems, are not in the least discontent with such a historical development of either the concept or the discipline. In addition, they neither delineate Potter's intention and conception in detail, nor do they trace the other, "Potterian" school of thought on bioethics. And they are not alone - their survey, much like Callahan's, is written in the spirit that still prevails amongst bioethical circles, the Anglo-American at the very least, because of which Whitehouse rightly complains that important surveys of bioethics fail to include Potter adequately, which, however, does not mean that they fail to mention him altogether.

In any case, it took quite some time to reintroduce Potter's original idea to the bioethical mainstream, which Potter himself worked hard towards. His book Global Bioethics: Building on the Leopold Legacy, published in 1988, has contributed tremendously to his efforts.

Global Bioethics still contains the fundamental ideas and inspirations of his so-called bridge bioethics, although in an amended, more detailed and expanded or elaborated form in the light of the up-to-then advances (and deviations) in bioethics:

"At the present time it is necessary to go beyond Leopold and beyond medical bioethics. We must recognize that over-specialization in either branch can be counterproductive to the goal of acceptable survival on a global scale. The two branches need to be harmonized and unified to a consensual point of view that may well be termed global bioethics, stressing the two meanings of the word global. A system of ethics is global, on the one hand, if it is unified and comprehensive, and in the more usual sense, if it is worldwide in scope." (Potter, 1988: 78)

In global bioethics Potter places special and even stronger emphasis on global-ecological question, ${ }^{11}$ and points to the need for bioethics to meet spirituality and politics already in this book and particularly in his later work.

Potter's Global Bioethics was much more successful than his first book, which ultimately eventuated in the Global Bioethics Network at the beginning of the 1990s. ${ }^{12}$ Nonetheless, even Global Bioethics has not been free from misunderstandings. In other words, much like what befell Potter's first book, many have borrowed its name but not its idea. Many, unfortunately, understand global bioethics in some "touristic sense", i.e. to be the globalisation of dealing with bioethics as biomedical ethics, or to be some global bioethical (i.e. biomedical-bioethical) conference tourism, which is, of course, entirely wrong and misses the point completely.

\section{VAN RENSSELAER POTTER'S BIOETHICS AS THE FOOTHOLD OF INTEGRATIVE BIOETHICS?}

The points of contact between the idea of integrative bioethics and Potter's bioethical idea should be clear by now from the above exposition of the two concepts.

\footnotetext{
${ }^{11}$ Moreover, Ludwig Siep claims that what Potter "principally had in mind is the problem of the conditions of the survival of the human kind and their cultures in a natural environment", and that that which Potter called bioethics is "that which is today called "environmental ethics' or 'ecological ethics" (Siep, 1998: 16). This claim is only partially true because Potter never lost sight of the problems concerning his primary and professional field of interest (and the fountainhead of bioethics), i.e. medicine and the life sciences.

${ }^{12}$ Potter talks about the origins and growth of the Global Bioethics Network in his bioethical testament, which he emailed shortly before his death (6 September 2001) to 38 of his closest associates devoted to reflecting on and to popularising his global bioethics (Potter, 2001).
} 
The need for a thorough reflection on and re-conceptualisation of bioethics at this high level of its development, including the questions of the definition and foundation of bioethics, as well as the need for a much more extensive understanding of it - are, most certainly, the first items on this list.

However, any joint reflection on the ideas of integrative and global bioethics must not take the path of only pinpointing their resemblances and correspondences since there are some significant and even fundamental differences between the two concepts. I shall point to them by identifying the main shortcomings of Potter's bioethics in three points.

Firstly, Potter's profound scepticism about today's science as a reductionist system of objective truths under the leadership of the natural sciences, his divergence from science thus understood and his consequent abandonment of all scientisation of bioethics are not problematic in themselves. After all, such tendencies have helped set bioethics going in large measure. Yet, as far as an alternative is concerned, Potter's intention is indeed disputable. More specifically, he holds that bioethics is not so much about knowledge and the communication of different types of knowledge, but that it is more about a life wisdom, ${ }^{13}$ which - as a personal credo - all mankind should start applying in their everyday life as a way of life. In this sense, Potter prefers talking about morality to talking about ethics. Moreover, the end of his Global Bioethics brings "A Bioethical Creed for Individuals" with a whole set of beliefs and commitments, i.e. a series of simply formulated instructions on how individuals are to conduct themselves in everyday life regarding their health and the environment (Potter, 1988: 193-195). In addition, although in Global Bioethics he stresses that global bioethics must be a secular bioethics, somewhat later and particularly in his last papers he gives more and more attention to the role of religion and "nature based religion". But, irrespective of bioethics having to show consideration for individual moral sensibilities and "personal ethical programmes", as well as for different religious approaches and religiosity as such, no ethical reflection can remain at that level. Hans Jonas asserts that:

"That which is to be appropriate for this issue must resemble steel and not cotton. There is more than enough cotton of good conscience and impeccable intentions (...) in today's ethical reflection." (Jonas, 1984: 9-10)

Potter makes the same mistake that so many other theoreticians do, as some of the socalled deep ecologists, for example - they try to evade the wasteland of the reductionist natural sciences and technology by taking a shortcut with the help of various religious, syncretistic-religious, quasi-religious and spiritualistic ideas. For example, Peter J. Whitehouse, Potter's close associate and follower, suggests expanding, i.e. deepening, global bioethics into deep bioethics, which, he continues, should introduce a spiritual dimension at the core of bioethics, i.e. the feeling of a mystical connection to nature (Whitehouse, 2003: 27).

The second shortcoming of Potter's bioethics is also not problematic in principle; it only later shows to be a problem in regard to the development and final shape of his basic idea. It pertains to the key intention of Potter's bioethics, which is bridging the gap between the natural sciences and the humanities, and, more importantly, between the questions concerning human health and the questions concerning the environment or nature, i.e. between biomedical and ecological issues. As concise and direct as always, Potter writes:

\footnotetext{
${ }^{13}$ Although such views are scattered throughout Potter's entire Global Bioethics and his subsequent work, the chapter title "From Knowledge to Wisdom" from Global Bioethics is indeed illustrative (Potter, 1988: 58).
} 
"The fate of the world rests on the integration, preservation, and extension of the knowledge that is possessed by a relatively small number of people who are only just beginning to realize how inadequate their strength, how enormous the task." (Potter, 1971: 2)

Ultimately, Potter confronts the mechanical separation of these problems and issues, which characterises both medicine and the natural sciences, with a mechanical integration such as of his own concept of "personal health" and Leopold's "land ethic" - without first reflecting on and explicating the integrative factors sufficiently.

It could even be said that Potter does not take seriously either the problem of interdisciplinarity or the questions of methodology, both of which are posed once the gathering of different disciplines, sciences, approaches, etc., becomes an imperative (or a recommendation at the very least). Daniel Callahan is clear about what in particular this problem is about:

"An interdisciplinary field is not necessarily well served by a tight, narrow methodology. Its very purpose is to be open to different perspectives and the different methodologies of different disciplines. Does this mean, then, that although parts of bioethics might be rigorous - the philosophical parts taken by themselves or the legal parts - the field as a whole may be doomed to a pervasive vagueness, never as strong as a whole as its individual parts? This is a charge sometimes levelled against the field, and it has not been easy for its practitioners to find the right balance of breadth, complexity, and analytical rigor." (Callahan, 1995: 250)

Indeed, Callahan himself has no firm and definite answer to the question concerning bioethical methodology and so he humbly concludes that bioethics as a new field seeks "to better define itself and refine its methods". But, in contrast to Potter, Callahan at least locates and articulates the problem.

There may not be a short, simple and definitive answer to the question of bioethical methodology (or the methodology of bioethics). But, from the perspective of integrative bioethics, where we should be looking for it is entirely clear. More specifically, the only methodology appropriate for bioethics is one that secures the success of the concepts of interdisciplinarity, pluriperspectivism, and integrativity. This is most certainly not the methodology of either an "exact" science or any other special science. The only methodology adequate for bioethics is integrative methodology, whose development could, according to Ante Čović, "establish a new paradigm - that of the third science" (Čović, 1998b), in contrast to the first (ancient) science with its integralistic methodology and the second (modern) science with its reductionist methodology (Čović, 1998b). In any case, the role of philosophy will be indispensable for the full scope of our discussion of methodology - from achieving and furthering an interdisciplinary dialogue concerning certain ethical questions to finding an epochal orientation for humanity in the perspective of the philosophy of history.

This clearly brings us to my third objection to Potter's bioethics. Moreover, the basic problem of his bioethics should at this point be obvious - the absence of a firm ground and a more precise apparatus, which, I believe, cannot be secured without the help of philosophy. In other words, only philosophy has the capacity to provide the terminological apparatus of the bioethical discourse and only philosophy can set the conceptual background and framework of this discourse, i.e. can conceptualise and realise transdisciplinarity, pluriperspectivism and integrativity, while also supplying solutions for both the general and particular problems of cultural and ethical relativism.

Admittedly, Potter does not exclude philosophy from his bioethical reflection. Quite the opposite, in his Global Bioethics Potter also tackles fundamental ethical problems and 
the question of the limitations of philosophy, i.e. criticism of philosophy (Potter, 1988: 80-84). However, his critical reflection on philosophy is, on the one hand, primarily based on secondary literature, and on the other, it in fact only regards Anglo-American philosophy, i.e. pragmatism and utilitarianism, although it is formulated as criticism of philosophy on the whole, from which it can be concluded that Potter was entirely unfamiliar with the Euro-continental philosophical tradition.

As a practicing scientist and doctor, Potter has most certainly stepped out from his primary field of interest and discipline, so it would probably be unreasonable to expect him to satisfy an insatiable philosophical-bioethical appetite, particularly because he was guided by intentions, visions and aims, whose worth is indisputable. Nevertheless, this is not a valid enough reason not to point to this shortcoming of Potter's conception, especially because he frequently does not arrive at obvious philosophical questions, and even when he does reach them he either disregards them all too easily or misses the point in answering them.

On the other hand, philosophy and philosophical ethics - first and foremost owing to their inherent integrative features - do play a major role in integrative bioethics, which is not in disagreement with the methodological principle of transdisciplinarity and pluriperspectivism.

This is what distinguishes integrative bioethics not only from Potter's, but also from a number of other bioethical conceptions. This interlacement of bioethics with philosophy, this philosophisation of bioethics does not mean that philosophy has appropriated bioethics, that bioethics is now to be treated as a sub-sub-discipline of philosophical ethics, which would benefit neither philosophy nor bioethics. The intention of the philosophisation of bioethics is, in principle, different from the intention of the so-called applied or practical ethics, which emerged and has been developing within the framework of Anglo-American philosophy.

Furthermore, the philosophisation of bioethics is at the same time the Europeanisation of bioethics, which is not in discord with the principle of interculturality and pluriperspectivism in general. The Europeanisation of bioethics refers to the activation of the potentials of the Euro-continental ethical or philosophical thought within the bioethical framework for bioethics to be able to fulfil its original purpose that cannot be achieved exclusively with the help of an approach that rests on a reduced understanding of bioethics either in terms of its problems and topics (biomedical or medical ethics, clinical ethics) or in terms of its disciplinal methodology (practical or applied ethics).

The process of the philosophisation of bioethics also implies the endeavour that could indeed be called the bioethicisation of philosophy. This means bioethically reading the leading authors and works of the Euro-continental philosophical tradition for the purpose of identifying both the footholds of establishing and developing dialogue between bioethics and philosophy, and the incentives to reflect on bioethical problems in partnership. It therefore seems to me that the revival and reinterpretation of, for example, Aristotle's knowledge and science triad could be of great use to the discourse on the fundamental, methodological questions of bioethics. Considering that Aristotle's systematisation is not only about drawing subtle differences between problems, approaches and fields, but also about identifying and developing immanent cohesive elements, this integrative triad could, if nothing else, be one of the stimuli in our search for possible models of bioethical pluriperspectivism and integrativity. In addition, a number of authors and their work, which might at first glance appear to be miles from the field of bioethics, could with an appropriate 
approach become inspirational to bioethicists. A superb example of this is the bioethical reading of Kant supplied by Thomas Sören Hoffmann in his paper "On Kant's Topicality for Bioethics" (Hoffmann, 2005). ${ }^{14}$ I also hold the work of Michael E. Zimmermann - devoted to establishing connections between deep ecology and Heidegger's philosophy, which is, although not under the name of bioethics, most certainly relevant to what I have here termed the bioethicisation of philosophy - to be fascinating (Zimmerman, 1983; Zimmerman, 1993; Zimmerman, 1997).

Yet, let me return to Potter. His global bioethics proves to be deficient primarily from the perspective of philosophy, i.e. of a philosophically aware bioethics. We could, in this sense, attempt to correct it, or rather supplement it with another developed, rounded and philosophically articulated bioethical conception. One such "operative procedure" could be performed with the help of Hans Jonas for example, whose "ethics of responsibility" (and "philosophical biology" in part) is in some of its aspects compatible with Potter's global bioethics. I shall indicate only a few points of contact: stressing the need to bridge the gap between the natural sciences and the humanities (Jonas's "philosophical biology" and Potter's "bridge bioethics"); designing the programme of a "new ethics" (Jonas's ethics of responsibility as an ethics of the future and macro-ethics for the technological civilisation, Potters' future-oriented global bioethics); Jonas's categorical imperative for the survival of humanity and life on the planet Earth and Potter's imperative for the long-term ("acceptable") survival of humanity; guiding the new (bio)ethical conception towards the field of political practice in both authors, etc.

However, considering that in Potter this is a "systemic error" so to speak, any attempt at correcting and reconstructing it would be all too extensive, and would ultimately and inevitably result in something that would no longer even resemble Potter's global bioethics.

With respect to the fact that the birth and development of Potter's bioethics is most closely tied to the birth and development of bioethics in general, co-thinking integrative bioethics and global bioethics is both valid and desired, particularly in respect of the stage that bioethics is at today. According to Peter J. Whitehouse, the reanimation of the original bioethical conceptions could "prevent the dementia of the field", which is characterised "by a selective amnesia of the past and inattention to certain critical issues for the survival of life on the planet". This dementia, Whitehouse continues, issues from "a dysexecutive disconnection syndrome, which relates to distorted goals and values" (Whitehouse, 2003: 30).

Agreeing in principle with Whitehouse's claim, from the perspective of integrative bioethics Potter's global bioethics most certainly deserves praise, but must also take serious criticism, which I have here tried to outline. Based on this it can be said that, in terms of its general starting points and general aims, the idea of an integrative bioethics is compatible but not identical with Potter's idea of global bioethics. This, in turn, means that integrative bioethics is simply neither a new embodiment of global bioethics nor a new stage in the development of Potterian global bioethics. Nevertheless, Potter's global bioethics can indeed be both a foothold and stimulus, i.e. one of the footholds and one of the stimuli, of integrative bioethics.

\footnotetext{
${ }^{14} \mathrm{Cf}$. also the bioethical reading of Kant's ethics by Heike Baranzke (2002).
} 


\section{REFERENCES}

Baranzke, H. (2002). Würde der Kreatur? Die Idee der Würde im Horizont der Bioethik, Königshausen \& Neumann, Würzburg.

Bauby, J.-D. (1997). The Diving Bell and the Butterfly, Alfred A. Knopf, New York.

Beauchamp, T. L., Childress, J. F. (1994). Principles of Biomedical Ethics, Oxford University Press, New York. Beauchamp, T. L. (1996). Načela u bioetici (Principles in Bioethics), Društvena istraživanja Vol. 5, No. 3-4, 1996, pp. 533-544.

Berthold, D. (2004). Aldo Leopold: In Search of a Poetic Science, Human Ecology Review, Vol. 11, No. 3, 2004, pp. 205-214.

Callahan, D. (1988). The Development of Biomedical Ethics in the United States. In Callahan, D., Dunstan, G. R. (eds.), Biomedical Ethics: An Anglo-American Dialogue, New York Academy of Sciences, New York, 1988 , pp. 1-3.

Callahan, D. (1995). Bioethics. In Reich, W. Th. (ed.), Encyclopedia of Bioethics, Vol. I, Macmillan, New York, 1995, pp. 247-256.

Callicott, J. B. (1987). The Land Aesthetic. In Callicott, J. B. (ed.), Companion to A Sand County Almanac. Interpretative and Critical Essays, The University of Wisconsin Press, Madison, 1987, pp. 131-171.

Čović, A. (1998a). La biopoétique et la bioéthique dans la prose existentiale de J.-D. Bauby Le scaphandre et le papillon, Synthesis philosophica, Vol. 13, No. 1, 1998, pp. 269-283.

Čović, A. (1998b). Wissen und Moralität, Synthesis philosophica, Vol. 13, No. 2, 1998, pp. 547-566.

Čović, A. (2005). Bioethik unter den Bedingungen des Postkommunismus - Fallbeispiel Kroatien. In Čović, A., Hoffman, Th. S. (eds.), Bioethik und kulturelle Pluralität. Die südosteuropäische Perspektive, Academia Verlag, Sankt Augustin, 2005, pp. 148-172.

Engelhardt, H. T. (1988). Foreword. In Potter, V. R., Global Bioethics: Building on the Leopold Legacy, Michigan State University Press, East Lansing, 1988, pp. VII-XII.

Fox, M. W. (2000). Bringing Life to Ethics. Global Bioethics for a Humane Society, State University of New York Press, New York.

Höffe, O., ed. (1997). Lexikon der Ethik, Beck, München.

Hoffmann, Th. S. (2005). Zur Aktualität Kants für die Bioethik, Synthesis philosophica, Vol. 20, No. 1, 2005, pp. 121-140.

Jonas, H. (1984). Das Prinzip Verantwortung: Versuch einer Ethik für die technologische Zivilisation, Suhrkamp, Frankfurt a. M.

Kuhse, H., Singer, P., eds. (2003). Bioethics: An Anthology, Blackwell, Malden et al.

Kuhse, H., Singer, P., eds. (2004). A Companion to Bioethics, Blackwell, Malden et al.

Leopold, A. (1987). A Sand County Almanac, and Sketches Here and There, Oxford University Press, New York.

Midgley, M. (2001). Science and Poetry, Routledge, London.

Pieper, A., Thurnherr, U., eds. (1998). Angewandte Ethik: Eine Einführung, Beck, München.

Potter, V. R. (1970a). Bioethics: The Science of Survival, Perspectives in Biology and Medicine, Vol. 14, No. 1, 1970, pp. 127-153.

Potter, V. R. (1970b). Biocybernetics and Survival, Zygon - Journal of Religion \& Science, Vol. 5., No. 3, 1970, pp. 229-246.

Potter, V. R. (1971). Bioethics: Bridge to the Future, Prentice-Hall, Englewood Cliffs.

Potter, V. R. (1988). Global Bioethics: Building on the Leopold Legacy, Michigan State University Press, East Lansing.

Potter, V. R. (2001). Global Bioethics Final Message. http://www.mcardle.wisc.edu/faculty/bio/ PotterGlobalBioethics.html.

Rehmann-Sutter, Ch. (2002). Bioethik. In Düwell, M., Hübenthal, Ch., Werner, M. H. (eds.), Handbuch Ethik, Metzler, Stuttgart, Weimar, 2002, pp. 247-252.

Reich, W. Th. (1995). Introduction. In Reich W. Th. (ed.), Encyclopedia of Bioethics, Vol. I, Macmillan, New York, 1995, pp. IX-XXXII.

Siep, L. (1998). Bioethik. In Pieper A., Thurnherr, U. (eds.), Angewandte Ethik: Eine Einführung, Beck, München, 1998, pp. 16-36.

Singer, P. (1993). Practical Ethics, Cambridge University Press, Cambridge.

Šegota, I. (1999). Van Rensselaer Potter II: 'Father' of Bioethics, Synthesis philosophica, Vol. 14, No. 1-2, 1999, pp. 169-182.

Trosko, J. E., Pitot, H. C. (2003). In Memoriam: Professor Emeritus Van Rensselaer Potter II (1911-2001), Cancer Research, Vol. 63, No. 7, 2001, p. 1724. 
Whitehouse, P. J. (2003). The Rebirth of Bioethics: Extending the Original Formulations of Van Rensselaer Potter, The American Journal of Bioethics, Vol. 3, No. 4, 2003, pp. 26-31.

Zimmerman, M. E. (1983). Toward a Heideggerean Ethos for Radical Environmentalism, Environmental Ethics, Vol. 5, No. 2, 1983, pp. 99-131.

Zimmerman, M. E. (1993). Rethinking the Heidegger-Deep Ecology Relationship, Environmental Ethics, Vol. 15, No. 3, 1993, pp. 195-224.

Zimmerman, M. E. (1997). Heidegger and Deep Ecology. In Embree, L. et al. (eds.), Encyclopedia of Phenomenology, Kluwer Academic Publishers, Dordrecht, 1997, pp. 137-141.

\section{UPORIŠTA ZA INTEGRATIVNU BIOETIKU U DELU VANA RENSELERA POTERA}

Uprkos još uvek postojećim tendencijama sužavanja pojma bioetike na (bio)medicinsku ili čak kliničku bioetiku, jasno je da bioetika danas objedinjuje rasprave o mnogo širem spektru pitanja, od biomedicinskih do globalno-ekoloških. Širenje predmetne oblasti bioetike jeste rezultat uvida o prepletenosti problema sa kojima se u tehno-naučnom dobu suočava čovek, i onih problema koji se tiču i drugih živih bića, te prirode u celini. Uvid o problemskoj prepletenosti (i prepletenosti samih odnosa unutar sveta živog) doveo je do umrežavanja različitih nauka, delatnosti i ne-naučnih pogleda, što poznajemo pod imenom multi-, inter-i trans-disciplinarnosti, te pluriperspektivizma. No, bioetika ne bi smela da se zadovoljava sa čisto mehaničkim okupljanjem različitih disciplinarnih i svetonazorskih pogleda, nego bi trebala da teži istinskoj integraciji, izrađivanju jedinstvene platforme za raspravu o etičkim problemima vezanim za život u svim njegovim formama, stepenima, fazama i pojavama. Razvijanje ovih početnih premisa jeste zadaća ,integrativne bioetike“. U izvršavanju te zadaće neizbežno je da se osvrnemo na delo Vana Renselera Potera, jer se njegova ideja bioetike i razvoj njegove bioetičke misli uvelike podudara sa onim što bioetika uopšte znači, te sa njenim istorijskim menama: od trena kada je skovao izraz 'bioetika', preko utemeljenja tzv. „mostovne bioetike“, do njene sadržajne reformulacije i proširivanja u tzv. „globalnoj bioetici“. Namera ovog rada je da se ispita u kojoj meri koncept integrativne bioetike može da nađe podsticaj i uporište u Poterovom delu.

Ključne reči: bioetika, integrativna bioetika, interdisciplinanost, pluriperspektivnost, Van Renseler Poter 